\title{
Who CAN BE EXAMINED For DISCOVERY: THE EVOLUTION OF RULE 200(1) AND ITS Application Under the Proposed Rules of Court
}

\author{
THOMAS H. FERGUSON, Q.C., \\ DOUGLAS T. YOSHIDA, “ AND \\ KIRSTEN A. TIIORESON ${ }^{* *}$
}

This article examines the evolution of $r .200(1)$ of the Alberta Rules of Court, begimning with the first formulation of r. 200(1) in the 19/4 Alberta Rules of Court and culminating in its draff form in the Alberta Rules of Coun: Test Draft 3. Rule 200/l) allows a party to examine for discovery the employees, former employes, and corporate representative of an opposing party in such circumslances where they have knowledge of the issues bencen the parties by nature of their employmen, without first ohtoining an order to do so. This article focuses on the presen application and interpretation of r. 200(l) byexamining the impact of no critical cases on the Rule. Then, the authors undertake a comparison of the present form of the Rute and the new form it will take under the Proposed Alberta Rules of Court. The authors conchde that the proposed Rule contradicts the broad and purposive approach that has been taken to the present Rule by reinstating an additional "best informed" test and adding threc addifional criferio.
Cot arficle axumine l's'volunion de la rigle 20)(1) des Règles de procédure de l'Alberta, en commencam par les premières versions do 200(l) dans la version dc $19 / 4$ des Règles pour ubourir à / ébauched essis 3. notamment Alberta Rules of Court: Test Draft 3. La règle 200(l) permel à tume partic dexaminer, en vo d'une enquéte préalable. les employés. anciens employes ef représentans dime partie opposét lorsque cenx-ci ont commaissume des problimes qui existen entre les portices a conse de la nature de leser emploi el ce, sums obrenir priatablement dortomance' i cet effer. Cer article cible Iapplication al inferprétation couramis de lo regle. $20(1)$ (I) in cxaminan l impact de deux comses critiques relatives à la règle. Les auteurs en comparent ensuite la forme actuelle et la nowelle forme en vertu des Rigles de procédures proposices fl'roposed Alberta Rules of Court). Les anreurs arrivem a la conclusion que la rigle propose compredit la veste approche colcule

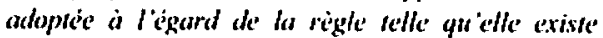
anjom d'mi en rioflirman im essat additionmel de a la commaissance de canse' "'f e'n ajoutam trois crifires addirionnels.

\section{TABLE OF CONTENTS}

I. INTRODUCTION ................................. 902

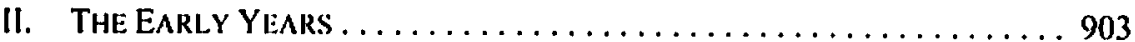

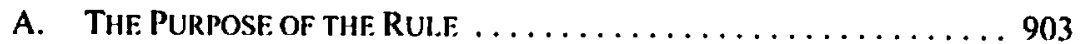

B. THE LEGISLATION FROM $1914-1944 \ldots \ldots \ldots \ldots \ldots \ldots \ldots . \ldots 93$

C. THE LEGISLATION FROM $1944-1999 \ldots \ldots \ldots \ldots \ldots \ldots \ldots . \ldots 93$

D. The Lfgislation from 1999 to Present . . . . . . . . . . . . 904

E. EARLy JUdicial CONSIDERATION .................. 905

III. The FIRST EXPANSION: CANA CONSTRUCTHON-

The “One Person, Best Informed” Test . . . . . . . . . . . . . 906

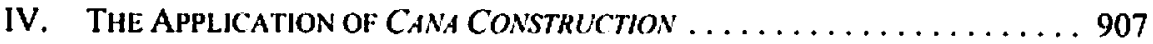

A. Lawyers . . . . . . . . . . . . . . . . . . . . 907

B. Consul.tants/COntractors $\ldots \ldots \ldots \ldots \ldots \ldots \ldots \ldots ., 908$

C. MischllaneoUs $\ldots \ldots \ldots \ldots \ldots \ldots \ldots \ldots \ldots \ldots \ldots \ldots \ldots$ 
V. THE COURT OF APPEAL'S RESTATEMENT:

PEtro-Canada - The Current Law ................. 914

VI. THE APPLICATION OF PETRO-CANADA .................. 916

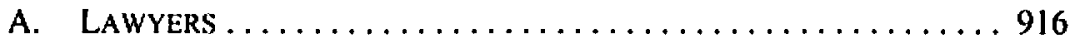

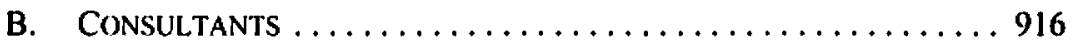

C. DiRECTORS ............................... 917

D. Crown Employefs $\ldots \ldots \ldots \ldots \ldots \ldots \ldots \ldots \ldots \ldots, \ldots 18$

E. Miscellanlous .......................... 919

VII. Comparing RULE 200(1) to the New RULE $\ldots \ldots \ldots \ldots \ldots \ldots, 920$

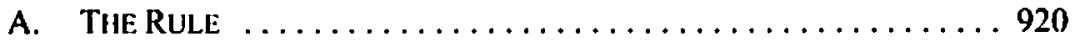

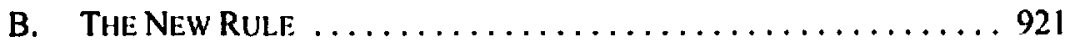

VIII. Operation OF THE New RULE $\ldots \ldots \ldots \ldots \ldots \ldots \ldots \ldots \ldots \ldots, 923$

IX. CONCLUSION .............................. 926

APPLNDIX A: CHRONOLOOGICAL. SUMMARY OF JUDICIAL

Consideration of Rule 200(1) Post-Cana Construction ........ 928

\section{INTRODUCTION}

Rule 200(1) (the Rule) of the Alberta Rules of Court' affords a party the right, without an order, to examine for discovery an opposing party and, in the case of a corporation, the corporation's representative and the employees and former employees who have knowledge of the matters raised in the pleadings as a result of their employment. Due to the object of the Rule, mainly to allow pre-trial disclosure of relevant and material information that is not privileged, an increasingly broad interpretation has been applied by the courts to the Rule through the progressive and expanding definition of who is considered to be an "employee."

Major shifts in the application of r. 200(1) can be marked by two key cases of the Alberta Court of Appeal: the 1986 decision of Cana Construction Co. Lid. v. Calgary Centre for Performing Arts ${ }^{2}$ and the 2004 decision of Petro-Canada Products v. Dresser-Rand Canada. ${ }^{3}$ As discussed below, the expansion and shifts in the application of the Rule were intended to improve:

(1) the timely disclosure of relevant information;

(2) the needs of increasingly complex modern litigation:

(3) The parties' ability to properly assess the strength of their case; and

(4) the settlement of disputes.

In order to evidence the increasingly broad interpretation being given to the Rule, the following analysis of the evolution of r. 200(1) focuses on these two cases and their respective applications to the various categories of witnesses, including lawyers, consultants, directors, officers, and public officials. 
This article begins by examining the early legislation and how it was applied. It then sets out the impact of the Cana Consiruction and Petro-Canada decisions, along with their respective judicial considerations. For convenient reference, a chronological chart summarizing judicial consideration of the Rule from Cana Construction onward is contained in Appendix A. Finally, this article considers the equivalent sections to the Rule under the Alberta Rules of Court: Test Draft $3,{ }^{4}$ rr. 5.17 and 5.18 (the New Rule) and its likely application.

\section{THE. EARL.Y Years}

\section{A. The Purpose of THe RULE}

The purpose of an examination for discovery is three-fold: (1) to obtain discovery or information as to the facts; (2) to obtain admissions which may be used as evidence against the party whose officer is examined: ${ }^{3}$ and (3) to obtain a transcript for use at trial. for impeachment purposes. The courts that performed early applications of the Rule were cognizant of these purposes and attempted to interpret the Rule accordingly. However, these purposes have been broadened over time, driven by the complexity of cases, increasing business litigation, and diversity of legal issues.

\section{B. THE LEGISLATION FROM 1914-1944}

In Alberta, the first Rule of Court with respect to the examination for discovery of officers and employees was passed in 1914. The Rule was subsequently revised in 1944 and again most recently in 1999. The Rule as it was first introduced in 1914 (the 1914 Rule), then numbered as r. 234, required an order and made no reference to an oath or to corporations. The 1914 Rule was the general rule pertaining to the examination of (1) a party, and (2) a present or past employee of a party who appeared to have some knowledge touching the questions in issue acquired by virtue of such employment. It provided:

A judge may order any party to an action. or any person who is or has becn employed by any party to an action and who appears to have some knowledge touching the questions in issuc acquired by virtuc of such employment. whether such party or person be wilhin or without the jurisdiction. to be orally examined hefore trial touching the matter in question by any person adverse in interest."

\section{THe LegisL,ATION FRON 1944-1999}

From 1944 to 1999, the Rule (the 1944 Rule), numbered as r. 240(1), was worded as follows:

- Alberta Law Keform Institule (ALRI). The Rules Project: Alherta Rules of Coner: Tes/ Drofi 3 (tiebruary 2007), online: ALRI Clap://www.law.ualberla.ca/alri/docs/ALRldrafi\%2(0Rules\%2001\%20 Court\%20TD3.pdi> |Proposed Rules of Comm|. m. 5.17.5.18. The date the Proposed Rules of Court comes into lorec is unknown as of the date of this anticle. It is also unknown if there will be future test drafts to alter this version of the New Rule.

- Nichols \& Shepard Co. v. Skedomuk (No. 2) (1912), 6 D.L.R. 115 (Alta. S.C.) at 116.

- Alberia Rules of Courr, 1914, r. 234. 
Any party to an action. any officer of a corporate party and any person who is or has been employed by any party to an action, and who appears to have some knowledge touching the question at issuc, acquired by virtue of such employment whether such party or person be within or without the jurisdiction, may be orally examined on oath or aftirmation before the trial of the action louching the matters in question by any person adverse in interest, without order. ${ }^{\text {? }}$

The most noticeable change from the 1914 Rule was that an order was no longer required under the 1944 Rule. Prior to the 1944 Rule, an order was required because a motion for directions was compulsory at the early stage of every contested civil suit. This requirement for a compulsory motion for direction also disappeared from the Rules of Court in 1944. ${ }^{8}$

\section{The Legislation from 1999 to Present}

In 1999, the Rule was amended to its current form. The Rule is now found under Division Two of the Rules of Court, "Examination for Discovery," under the subtitle "Oflicers or employees of corporation" and provides as follows:

200(1) Before trial, a party to procecdings may orally examine under suth, without an order of the Court.

(a) any other party to the proceedings who is adverse in interest,

(b) if the other adverse party is a corporation, one or more oflicers of the corporation, and

(c) one or more other persons who

(i) are or were employed by the other party, and

(ii) have or appear to have knowledge of a matter raised in the pleadings that was acquired by virtue of that employment. ${ }^{9}$

When the 1944 Rule and the current Rule are reworked into the same sentence structure, ${ }^{10}$ it becomes clear that the differences between them are minimal. "While the 1944 Rule made an express allowance for examination to be done under affirmation, the current Rule makes no such mention. The 1944 Rule required employees for examination to have "some knowledge touching the question at issue" while the current Rule requires "knowledge of a matter raised in the pleadings." While the current wording is presumably more restrictive, this does not seem to affect the judicial consideration of the current Rulc.

The most significant difference between the 1944 and 1999 Rules is the latter's express allowance for "one or more" persons to be examined, whereas the 1944 Rule only allowed

Rutes of the Supreme Court of Alberia, 1944, r. 240.

As expluined by Còté J.A. in Wilbur v. Foothills Hospitat, 2005 ABCA 220, 367 A.R. 191 at paras. 2122 |Wilhur|.

Rules of Courl, supra note I. r. 200 (1).

The 1944 Rule can be restructured as follows: "I3efore the trial of the action, any person adverse in interest may orally examine on oath or affirmation, without order, (1) any party to the action. (2) any oflieer of a corporate party, and (3) any person who (a) is or has been employed by any pany to the action, and (b) who appears to have some knowledge touching the question at issue, acquired by virtue of such employment."

The majority in Tremco Inc. v. Gienow Building Products LAd, 2000 ABCA 105, 255 A.R. 273 at para. 13 [Tremco], implied that the only major difference was the "parsing" of the sections. 
for the examination of "any" party, officer, and employee. As discussed below, this clarification was called for by the case law. ${ }^{12}$

\section{E. Early Judicial Consideration}

The first application of the Rule occurred in 1916 in McLean v. Canadian Pacific Railway. ${ }^{13}$ In McLean, the Appellate Division of the Supreme Court was quick to note the limitations of the Rule, in that employees could only be examined when they were directly connected with the transaction or the occurrence, not merely as witnesses, but by reason of the character of their employment. ${ }^{14}$ However, even at that early stage, the Court allowed for the examination of multiple employees at first instance, where it was clear that each of the employees held a different position within the defendant corporation. Therefore, the plaintiff was not limited to the examination of only one representative person selected by the corporation.

Over time, the Rule continued to evolve through further judicial consideration. It was held that in permitting the examination for discovery of an employee, the burden of proving employment was on the party asking for the examination. ${ }^{15}$ This continues to be the case under current authorities. The limitations of the Rule noted in McLean continued to be followed and were applied so that persons acting as agents were not considered employees of their principals and were therefore not subject to examination. ${ }^{16}$ The same reasoning was also later applied to dismiss the examination of consultants. ${ }^{17}$ The application of the Rule was also considered with respect to lawyers where it was held that a solicitor, while acting for a client in his professional capacity, was not an employee of the client, and was therefore not subject to examination under the Rule. ${ }^{18}$ Initial examinations of lawyers were thereby limited to questions as to whether the lawyer was acting professionally and what communications the lawyer had made to the adverse party. The onus of establishing that the lawyer was acting as an employee and not in the usual capacity as solicitor was on the party asking for the examination. $^{19}$

See e.g. Mikisew Cree First Nation v. Canada, 2000 ABQ13 485, 267 A.R. 338 at para. 26 [Mikisew]. (1916), 28 D.L.R. 550 (Alla. S.C. (A.D.)) [McLean].

lbid. at 552.

Hoskins v. Minneapolis Threshing Machine (1930), 2 D.L.R. 696 (Alta. S.C. (A.D.)) .

Ibid. at 698 .

Marine Pipeline \& Dredging Lid. 1. Canadian Fina Oil Lnd. (1964), 46 D.L.R. (2d) 495 (Alta. S.C. (A.D.)) [Marine Pipeline]. Note that the narrow question pul to the Court in that case was whether all indicia of employment were present. The Court was not asked to decide whether the persons in question were officers within the meaning of r. 200(1).

See De la Giroday' McCaffery. [1930] 2 W.W.R. 576 (Alta. S.C.); Kirdeikis v. Campbell Bros. Real Esiare Lid. (1963), 39 D.I.R. (2d) 549 (Alta. S.C. (A.D.)) [Kirdeikis].

Kirdeikis, ibid. at 551. 


\section{THE First EXPansion: CANA CONSTRUCtion- THE "ONE PERSON, BEST INFORMED" TEST}

The first significant judicial consideration of r. 200(1) came in the Alberta Court of Appeal decision of Cana Construction. ${ }^{30}$ This was the first time the Court expanded the Rule's definition of "employee and officer," and constituted the leading case on the Rule until 2004 when the Court of Appeal decided Petro-Camada." Cana Consiruction was an action against a charitable organization which had undertaken the construction of a building. The charitable organization had delegated the supervision of its construction program to a committee. The committee had in turn named a volunteer as its chairman.

The plaintiff sought an order to compel the attendance for discovery of the unpaid volunteer chairman, since he had performed a key and relevant executive responsibility for the defendant. The trial judge dismissed the application. However, on appeal, the volunteer was ultimately compelled to attend at an examination for discovery for the plaintiff.

On appeal, Kerans J.A., for the Alberta Court of Appeal, first emphasized that the purpose of r. 200(1) was to be distinguished from that of r. $214,{ }^{22}$ which permitted the examining party not merely to gain information but also to gain formal admissions. It was held that while care should be exercised when interpreting the word "officer" in r. 214 so as not to undermine the policy behind that rule, a more generous interpretation could be afforded to r. $200(1)$. Therefore, case law on r. 214 would have no bearing on any case interpreting r. $200(1)$.

Justice Kerans then reviewed the authoritative case law on the equivalent Rules of Court in British Columbia, ${ }^{33}$ Saskatchewan, ${ }^{2+}$ and Manitoba. ${ }^{35}$ The Court emphasized that the limiting factor with respect to $r$. 200(1), that the person to be examined have some connection with the party as an officer or employee, was to be given a wide application. The Court then agreed with the B.C. Court's articulation of the r. 200(1) test, which was that a person sought to be examined could be regarded as an officer or servant if that person was "the one person connected with the company best informed of matters which may define and narrow the issues between the parties at the trial."

Applying this test, the Court held that the volunteer chairman met the definition of "officer" for the purposes of $r$. 200(1). The fact that the witness was an unpaid volunteer did not detract from the fact that, for the purposes of r. 200(1), he was an officer who had relevant information. Thus, Cana Construction represented a significant expansion of the scope of the Rule.

: Cima Consirtiction, supra note 2 at para. 5. For r. 214, sec Rules of Court, stupra note I.

2) Sec Rell v. Klein (No. 3), [1954] 12 W.W.R. (N.S.) 206 (B.C.S.C.) [Bell].

$\therefore \quad$ See Rennie v. Rural Municipality of Elma, [1946] ] W.W.R. 4 I I (Sask. C.A.).

25 See Neon Products Lid. v. Wiebe, [1974] 3 W.W.R. 567 (Man. Co. Ct.).

:Cana Construction, supra note 2 at para. 8, citing $O$ 'Halloran J. in Bell. supra note 23 [emphasis added]. 


\section{THE APPIICATION OF CANA CONSTRUCTION}

Between the 1986 decision of Cana Construction and the 2004 decision of Petro-Canada. the Court of Appeal's "one person, best informed" test was applied and modified to fit various categories of witnesses, including lawyers, consultants/contractors, and public officials.

\section{A. LAWYERS}

Though early cases indicated that lawyers were not examinable under r. 200(1) while acting for a client in their professional capacities, ${ }^{27}$ cases post-Cana Construction began to note further exceptions allowing for the examination of lawyers. In Simpson 's Num Ti Jah Lodge Lid. v. Lange, ${ }^{28}$ Waite J. held that lawyers could be examinable in their capacity as officers of the corporation, even where they were acting as lawyers for the corporation at the material time. ${ }^{29}$ In Simpson's, the lawyer was negotiating the terms of the contract at issue in the action. The fact that the witness was a solicitor was an impairment to his examination only to the extent that privilege could be raised in response to some of the questions put to him.

In BTK Holdings Lid. v. Greater Edmonton Development Corp..$^{30}$ the appellant argued, on the basis of Cana Construction, that a solicitor acting solely for a client company in the capacity as a solicitor may be examined as an officer of the company under r. $200(1))^{31}$ The Alberta Court of Appeal ruled that a solicitor for a corporate litigant who acted solely in the capacity as a solicitor cannot be considered the one person connected with the company best informed of matters which may define and narrow the issues between the parties at trial. ${ }^{32}$ The Court reached this conclusion because of the potential difliculties in separating privileged from non-privileged information. ${ }^{33}$ However, the Court left open for future consideration a situation in which a solicitor was acting in an additional or other capacity. In this case, there was no such evidence before the Court.

Despite concerns regarding the difficulty in separating privileged from non-privileged information, corporate witnesses were asked to inform themselves of any non-privileged information and then answer all questions in discovery to the extent that they were not protected by privilege. ${ }^{3.4}$ The Court of Appeal's decision was distinguished by Watson J. in Flynn v. Luscar Lid. ${ }^{35}$ a wrongful dismissal action. Justice Watson upheld Master Funduk's order for a solicitor's attendance for examination for discovery. He noted:

Sec for instance, Kirckikis, supra note 18. (1991), 126 A.R. 19 (Q.13.) [Simpsom's].

thid.

(1992), 131 A.R. 387 (C.A.) $[B T K]$.

Ibid. al para. 2.

Ibid. at para. 4.

Ihid, at para. 7.

See 474562 Alberla Lid. I. J.If. Nison /loldings Ldd. 1998 ABQB 1046, [1998] A.J. No. I331 (QL). 2002 ABQB 799, 323 A.R. $241[F / y m]$. 
A lawyer who is an eyewitness to a vehicle collision involving a client or even two clients is not in that regard using solicitor-client eyes and ears. A lawyer who acts as a form of business representative is not necessarily in the capacity of providing solicitor-client advice under circumstances of reasonably apprehended confidence either. ${ }^{36}$

Justice Clarke, for the Court of Queen's Bench, went even further in Klemke Mining Corp. v. Shell Canada Lid. ${ }^{37}$ where the Court was asked to consider whether a lawyer who worked exclusively as counsel for Shell Canada Ltd. (Shell) was examinable as an employee pursuant to $r$. 200(1). After reviewing the solicitor's contract with Shell, Clarke J. concluded that the solicitor's duties were equivalent to that of in-house counsel and also fit the traditional definition of employee, making her examinable under r. 200(1). Although the solicitor was acting in a professional capacity, she remained an employee for the purposes of the examination. Justice Clarke also noted that even if the solicitor was not in fact an employee of Shell, she would nonetheless be examinable as an officer of the corporation, under the principles established in Cana Construction. ${ }^{3 \mathrm{~K}}$ Though Clarke J. acknowledged both Kirdeikis and $B T K{ }^{34}$ he held that the solicitor was to be examined on what she heard and the extent to which she participated in negotiations towards an alleged contract, which was found to be separate from her work as a solicitor. Therefore, while privilege could be raised in response to some questions, the solicitor could still be examined on her attendance at the negotiation meetings in question. ${ }^{40}$ However, it should be noted that the focus of Klemke appeared to be whether the lawyer fit the definition of "employee," as she was actually a contractor. This issue is a recurring theme in the authorities addressing r. 200(1).

The underlying ratio of the above cases is that solicitors may or may not, while performing certain types of duties, be employees and thus subject to examination. A solicitor for a corporate litigant who acts only in his or her capacity as solicitor, and not in an additional or other capacity, is not within the definition of "officer" and is not subject to examination on privileged information. Otherwise, discovery of a solicitor is impaired only to the extent that privilege may be raised in response to some of the questions.

\section{B. Consultants/Contractors}

The principles articulated in Cana Construction have been applied extensively to persons not directly employed by the party in question, such as contractors, consultants, and agents. One of the earliest and most significant such applications came in the case of Trizec Equities Ltd. v. Ellis-Don Management Services Lid." The underlying claim arose from the movement of soil during excavation for a building. Two of the persons sought to be examined were employees of an accounting firm hired by the plaintiff to develop and prepare a claim for delayed occupancy as part of a larger claim for business interruption. Two of the firm's employees were assigned this responsibility by their employer, but under the direction of an

thide. at para. 65.

2002 ABQB II3], 332 A.R. 154 [K/emke].

lbid. at para. 23.

libid. at para. 29.

See also MacKenzic v. First Marathon Securities Ltd., 2004 ABQB 300, 130 A.C.W.S. (3d) 266, for the most recent Alberta case with a similar holding. 
officer of the plaintiff. They did not have first-hand information but were required to rely solely on information provided to them by the plaintiff.

The third person sought to be examined was a geotechnical engineer who had provided a professional opinion to the plaintiff after the shoring wall had moved. It was argued by the defendants that the employees of the accounting firm were most knowledgeable about the details of the plaintiff's business interruption claim, and that the engineer had full and complete knowledge of how the soil problem was remedied. On that basis, it was argued that these persons could be properly treated as officers or employees of the plaintiff. This argument was not accepted and the motion was dismissed.

The timing of the hiring of the consultants in Trizec was perhaps the most significant factor for Moore $\mathrm{C}$.J. in reaching his conclusion that the consultants were not employees for the purpose of r. $200(1)$. None of the consultants the defendant sought to examine for discovery were retained prior to the movement of the shoring wall. He found the knowledge that they possessed developed as a consequence of being arm's length consultants and not as employees.

The reasons from Trizec were followed in Adams $v$. Norcen Energy Resources Ltd. to allow the examination of employees from an outplacement consulting firm hired to assist with the termination of employees. ${ }^{+2}$ Though Adams was also decided by Moore C.J., the result was distinct. The lack of an arm's length relationship between the consultants and the employer was a strong factor favouring the discoverability of the consultants in Adams. Chief Justice Moore considered the comparisons to Trizec, ${ }^{43}$ and emphasized that the consultants in Adams were directly involved in the events which founded the plaintiffs' cause of action, whereas the consultants in Trizec were not involved in any events which constituted the cause of action.

In Small Bridge Investments LId. v. Batlle, ${ }^{44}$ Master Funduk allowed the examination of a consultant who had become the managing director of operations for a party. The defendants applied for an order requiring a former consultant of the plaintiffs to be produced for examination for discovery. The consultant was cmployed by a contracting company, who in turn entered into a contract with the defendants to provide management services. The consultant's job title was "managing director of operations." Master Funduk agreed with the holding in Trizec, but found that the case also allowed for the examination of "quasiofficers," those who, while not true oflicers, perform functions that are broadly equivalent to those performed by traditional officers. ${ }^{\text {t5 }}$ Therefore, he found that regardless of the fact that the consultant was actually employed by another company, the consultant was an officer of the plaintiffs within the context of r. 200(1).

In Edmonton (City of) v. Lovat Tumnel Equipmen, ${ }^{46}$ Wilson J. ruled that an employee of an enginecring consulting firm who was operating in the position of a general superintendent 
on a project for the City of Edmonton was an employee of the City within the meaning of r. 200(1). He came to this conclusion even though their relationship was far removed from traditional employer/employee relationships. From his review of Cana Construction and the cases which followed, Wilson J. identified a developing trend in the law expanding the discovery of persons who might be examined in complex litigation.

Chief Justice Moore further clarified the issue of examining consultants in Mikisew ${ }^{47}$ stating that the case law was clear: consultants may be examined under r. $200(1)$ if it is "appropriate" to do so. Similar to the "quasi-officer" consideration in Small Bridge, Moore C.J. found that the test under r. $200(1)$ is not whether a person is an officer or employee, but whether that person is "akin to an officer or employee." This test is part of the broader approach that is repeated and followed in subsequent authorities.

In Mikisew, Moore C.J. found that a consultant who performed functions broadly equivalent to those of an employee of the Band could be examined under r. 200(1) as an employee. In response to the Band's argument that such a ruling would open the floodgates of examination for discovery because aboriginal bands rely so heavily on external consultants, he stressed that he was not establishing a blanket ruling with respect to all consultants. $^{.8}$

Chief Justice Moore then proceeded to clarify another aspect of r. 200(1), stating that examinations under the Rule were not to be limited to a single person with the "best" evidence. Such an interpretation of Cana Construction would be contradictory to the express language of the statute, which allowed for the examination of "one or more" officers and employees."

Regardless of Moore C.J.'s clarification, it should be noted that references to the "best" informed witness continued in subsequent case law. In Johnson ". Alberta (Public Works Supply and Services), ${ }^{50}$ Romaine J. applied the "best" informed test to a class of persons, a group of surveyors, rather than to a single individual. ${ }^{51}$ It is interesting to note that the defendant did not have surveyors on staff, with the consequence that all the surveyors who were under contract to the Crown were found to be akin to employees.

A summary of the principles that emerged from these cases with respect to consultants was provided by Moreau J. in Alherfa-Pacific Fores/ Industries v. Ingersoll-Rand Canada, 52 which was an appeal from a Master in Chambers decision. The Master in Chambers dismissed an application by the defendant for an order requiring the plaintifl to produce a consultant engineer for discovery whose services had been retained to address machinery problems at the applicant's pulp mill. The Master in Chambers concluded that the engineer was not an officer or employee within the context of r. 200(1), and therefore was not subject to examination for discovery. However, Moreau J. overturned the Master in Chambers,

\footnotetext{
1) Silpra notc 12.

t* Hid. at paras. 23-26.

(1) Ihid. al para. 26.

4) 2002 ABQB 1068,329 A.R. 387.

$\therefore \quad$ bid. at paras. 22, 25.

$\because \quad 2002$ ABQB 791,326 A.R. 210 at paras. $29-30$.
} 
To summarize the principles that emerge from the case authorities:

1. Whether a persion is subject to discovery under Rule 200(1) must be determined on a case-by-case basis: Adams, supra: Mikisew ... supra:

2. The burden rests on the party seeking to examine an individual under Rule 200 (1) to establish the employment relationship with in the context of the Rulc: Marine Pipeline. supra;

3. The limiting factor in Rule 200(1), that the person to be examined have some connection with the party as oflicer or employec. should be given a wide application: Cama Comstruction, sturor;

4. The connection between an individual and a corporate pany should be more than a simple contractor's arm's-length relationship: Trizec ... supra;

5. The court should consider whether the individual was performing functions that were broadly equivalent to those performed by traditional olficers and employees: Trizec ... supra.

Factors emerging lirum the cases I have referred to that assist in determining whether an individual is subject to examination under Rule 200(1) are whelher the individual had execulive responsibilities for the corporation, whether the individual had direct knowledge of the circumstances, whether some of that knowledge was exclusive or first-hand, whether the cause of action arose prior to the individual becoming involved, how the corporation held the individual out to other parties and how he/she was viewed by other parties. $^{53}$

While Moreau J. did not expressly apply the "akin" test from Mikisew, the ultimate holding is quite similar, with a focus on functions "broadly equivalent to those performed by traditional employees."

\section{Miscellaneous}

In addition to the numerous cases on lawyers and consultants, Cana Construction has also been applied to various other categories of individuals for examination for discovery under r. 200(1), including public officials, former employees with after-acquired information, and persons who have worked for the plaintiff and the defendant.

\section{Public Officials}

Cana Construction has been applied in several instances to enable the examination of public officials under r. 200(1). In fact, in the first Court of Appeal case to apply Cana Construction, the issue was the examination for discovery of a minister of the Crown. In 
Lecds v. Alberta (Minister of Environment)," one of the issues was whether ministers were compellable for the purposes of $r$. 200(1). In Leeds, the plaintiffs owned certain lands which became part of a restricted development area (R.D.A.), therefore subject to Edmonton R.D.A. Regulations. After this designation, the plaintiffs repeatedly asked the Crown to acquire the land but no action was taken. Proceedings were instituted under the Expropriation Act ${ }^{36}$ and a certificate of approval was filed, whereupon the lands vested in the Crown. The respondents requested that certain employees and ministers of the Crown be made available for discovery but were informed by the Crown that only one officer would be made available for examination for discovery. At examination for discovery the officer refused, on the advice of counsel, to answer questions relating to the imposition of the R.D.A. and the steps taken to expropriate the land on the basis that they were irrelevant. The plaintiffs sought orders compelling the Crown to produce five employees or former employees for examination for discovery, compelling three ministers or former ministers of the Crown to appear and be examined for discovery, and compelling the officer produced by the Crown to re-attend at examination for discovery to answer questions he had refused to answer. The Chambers Judge ordered that the employees and ministers appear for examination for discovery and that the officer answer questions in relation to some matters but not others.

On appeal, the Crown argued that a minister could not be compelled to attend an examination for discovery because he is neither an officer nor an employee of the Crown. Justice Harradence, for the Court, concluded that if the action is brought under the Proceedings Against the Crown $A C t,{ }^{57}$ a minister can be subject to examination for discovery under r. 200(1). Since the purpose of the $P A C A$ is to place the minister in the same position as an officer of a corporation, they are subject to examination for discovery under the Rule. However. Harradence J. appeared to follow Cana Construction when he ruled that no minister of the Crown should be examined unless he is the best informed on the matters sought to be examined. ${ }^{\text {sx }}$ In leeds, the ministers were not compellable because there was nothing in the evidence to support a linding that the ministers were the best informed.

Conversely, r. 200(1) has been held not to apply with respect to mayors. In Olds (Town of) v. McDonald, ${ }^{39}$ Sulatycky A.C.J. found that a mayor was not an officer or an employee of a municipality, pursuant to the Municipal Government Act. ${ }^{60}$ This was despite the fact that the MGA expressly defined municipalities as corporations. Justice Sulatycky noted that the analysis applied to mayors under $r$. 200(1) could not be analogous to that used for ministers, as in leeds, given the separate picess of legislation that governed the two categories of officials." While ministers of the Crown are defined as officers under the $P A C A$, in contrast, the $M C A$ does not make mayors oflicers. Accordingly, it was held to be inappropriate to

$"$ R.S.A. 2000, c. P-25|PACA]

s* Lecds, sumpa note 55 al para. 41 . This approach has been crilicized by other courts of appeal: sec Nova Scotia (A.G.) v. Roral de Sim Alliumce insurance Co. of Cancuda, 2005 NSSC 126, 233 N.S.R. (2d) 280 at para. 33.

(4) 2003 ABQB 682, 333 A.R. 393 [Olds].

(A) R.S.A. 2000, c. M-26 [MGA $]$.

- Olds, supra nule 59 at para. 29. 
draw an analogy between the two public official positions. Consequently, mayors are not compellable for examination for discovery under r. 200(1).

\section{FORMER EMPLOYEES WITH AFTER-ACQUIRED INFORMATION}

The timing of the acquisition of information was central to the application of r. 200(1) in Tremco. ${ }^{62}$ A key issue was whether former employees could be compelled to answer questions with respect to information they acquired after their employment had terminated. Justice Dixon, the case management judge, decided that a witness must respond if the information is within his personal knowledge, even if the information was acquired while the witness was no longer employed by the party corporation. On appeal, Fruman J.A., speaking for the majority of the Court, noted that the scope of discovery was limited only by the phrase "relevant and material questions," in r. 200(1.2). To further restrict questions asked of former employees to matters "touching the question at issue acquired by virtue of their employment" would be inconsistent with the plain reading of the Rule. ${ }^{63}$ Nor was the scope of discovery limited to knowledge which might bind the corporate party or to evidence which might be admissible against that party. This was based on the broad purposes underlying the Rule: to gather information about the facts and to gain admissions which may be used in evidence against a party to the action. Therefore, the scope of discovery remained broad and unlimited by the capacity in which the information was obtained.

However, there was a strong dissenting judgment in Tremco. Justice O'Leary would not have compelled the witnesses to testify regarding after-acquired information based on several policy reasons. First, he noted that to allow such a scope of examination would risk the interminable protraction of litigation, with a corresponding increase in cost. Second, he found that it would result in a haphazard and unfair discovery process, where one party may be entitled to more extensive discovery than another based solely on the coincidence that one had former employees with personal knowledge or expertise relating to the matters raised in the pleadings. ${ }^{64}$ While this dissent does seem logical in the classic procedural sense, the majority was clearly following the growing trend of broadening the rules of discovery.

\section{Persons who have Worked for both the Plaintill and the Deilendant}

An interesting issue arose in the case of Rennick \& Di Pinto v. Coopers \& Lybrand, when the person requested for examination under r. 200(1) had previously performed accounting services for both the plaintiffs and the defendants. In Rennick, the witness had first worked for the defendants as an accountant, providing professional services at the time the plaintiffs alleged the defendants had provided negligent professional services. Shortly thereafter, however, the witness worked for the plaintiffs to assist in responding to Revenue Canada's inquiries and the ultimate audit of the plaintiffs in respect of the same time period. The witness was voluntarily produced by the plaintiffs as their employec/officer to be examined by the defendants and he answered a number of questions. However, the plaintiffs 
objected to him providing information he had obtained while he worked for the defendants. The defendants applied for an order directing the accountant to re-attend examinations for discovery as an employee/officer of the plaintiffs and to answer questions with respect to information relevant to the action which was acquired while he was in the defendants' employment.

Both the plaintiffs and the defendants in Rennick argued for different applications of the ratio provided by the Court of Appeal in Tremco. The defendants relied upon Tremco to support their claim of entillement to further examine the employee on the knowledge he acquired by virtue of his employment with the defendants. In contrast, the plaintiffs argued that the application of Tremco to the facts in Rennick should be viewed in the context of the employee's unique status in the action, the purposes of examination for discovery (including the fact that the defendants had been able to fulfill those purposes based upon the examinations to date), and the purpose of cross-examination in particular. ${ }^{66}$ The plaintiffs further argued that the ratio of Tremco was limited to the proposition that a former employee of a party adverse in interest can be examined on relevant information acquired after employment ceased. Since the defendants in Remmick could clearly not be adverse in interest to themselves, it was submitted that this was a very different situation than was before the Court of Appeal in Tremco.

Justice Lee disagreed with the plaintiffs and held that once a person was a proper subject of discovery, they were required to answer all relevant questions, irrespective of where the information was acquired. The phrase "acquired by virtue of that employment" in r. 200(1) was held to relate to the "'who' part of the test, but [did] not limit the 'what' part of the test." ${ }^{67}$ The accountant was therefore a proper subject for full examination by both the plaintiffs and the defendants, regardless of whether his information had been acquired in his employment by the defendants or the plaintiffs.

\section{THE COURT OF APPEAL's RESTATEMENT: Petro-Canada - The Current law}

The Court of Appeal in Petro-Canada ${ }^{68}$ restated and expanded on the law with respect to r. 200(1). The reasons provided in Petro-Canada have taken r. 200(1) to an advanced stage and as such, the case remains the leading decision in Alberta. The Court of Appeal asked the narrow question " $[w]$ hat is the proper test under $[r] .200(1)$ in determining whether a person is an employee or former employee?" ${ }^{\prime \prime 9}$ and found that prior case law had not yet clearly articulated such a test.

The appellants relied on Cana Construction for the proposition that where individuals were not officers or employees in the traditional sense, r. 200(1) should be interpreted to limit examination to those individuals who are "best informed." Justice Paperny, speaking for the Cour, rejected this interpretation since, on its face, the Rule did not purport to limit

Ibid. at paras. 23-24.

67 Ibid. at para. 51.

ax Supra note 3.

at Ibid. at para. 4 . 
examination of potential witnesses to the person or persons who were best informed. Indeed, such an interpretation expressly contradicted the Rule because "best" is a superlative and suggested but one person in that category. Rule 200(1) placed no limit on the number and r. 200(2) expressly contemplated examination of more than one employee. Furthermore, such a test was simply not practical since in many instances there may be more than one person who may be examined as best informed, depending upon the issues and facts of a particular case. Moreover, to require proof that the opposing party's employec was the "best informed" before the person was examined would put the party seeking discovery in an interesting Catch-22 situation. ${ }^{70}$ Therefore, "best informed" could not be used as the test to restrict the persons available for discovery under r. 200(1) and was held to be a relatively meaningless phrase in the context of the Rule.

Justice Paperny provided a general review of the Court of Queen's Bench cases which had addressed the Rule after Cana Consiruction. After considering a significant number of the above-mentioned cases, she held that while no definitive test had been stated, other than paraphrases of the decision in Cana Construction, several common threads could be gleaned from the authorities. She provided a non-exhaustive list of criteria to consider when determining who can be examined for discovery pursuant to r. 200(1):

1. Whether a person lits through the "narrow gateway" must be determined on a case-by-case basis;

2. The burden rests on the party seeking to examine to establish a relationship akin to employment;

3. The person must have relevant knowledge acquired by virtue of that relationship;

4. The Rule should be given a wide and purposive interpretation as pre-trial disclosure of relevant and material evidence is beneficial to the litigation process, facilitating settlement or narrowing the real issues in dispute;

5. The court should consider the nature of the functions performed by the person in question and whether they are broadly equivalent to those performed by traditional oflicers and employees.

Justice Paperny concluded her analysis of the issue with an articulation of a new test. Under the new test there are two requirements with regard to who may be examined under r. 200(1): first, "a relationship based on certain indicia akin to employment," and second, "relevant knowledge by virtue of that employment." The first requirement appears to have flowed from the "akin" test first stated in Mikisew. The test provided in Petro-Canada is now the law of Alberta and is to be applied to all future applications. 


\section{THE APPLICATION Of PETRO-CANADA}

Since the 2004 decision of Petro-Canada, the courts have continued to apply a broad and purposive interpretation to the Rule, though now perhaps with greater focus, especially with respect to whether witnesses are "akin to employees."

\section{A. LAWYERS}

One year after Petro-Canada was decided, the Court of Queen's Bench revisited the issue of examination for discovery of lawyers. In Domcan Boundary Corp. v. Enron Canada Corp. ${ }^{73}$ the issue was whether in-house counsel could be examined as employees or former employees pursuant to r. 200(1). Justice Hart commented that the Alberta Court of Appeal had held that $r$. 200 should be given a broad application as the timely disclosure of relevant information assists parties in properly assessing their case and that of their opponents well before trial. He noted the criteria set out in Petro-Canada and ultimately followed the trend established by the authorities, holding in-house counsel to be examinable under the Rule subject, of course, to solicitor-client privilege, and any other valid objections.

\section{B. Consultants}

Following Petro-Canada, the first case to address an application to examine a consultant was Resortport Development Corp. v. Alberta Racing Corp. ${ }^{74} \mathrm{Justice}$ Wilkins determined whether the defendants were entitled to examine two architects and two design engineers engaged by the plaintiffs. Without citing any authorities, Wilkins J. found that the Rule only applied to those persons whose relationship with the plaintiffs was "akin to employment."7s Based on Wilkins J.'s review of the facts, one can note that all of the factors for consideration enumerated in Petro-Canada were in favour of the applicants and therefore that the architects and design engineers had a relationship with the plaintiffs that was akin to employment. The individuals and their firms were engaged and performed services before and during the time that the cause of action arose. Their firms were entitled to be paid by the plaintiffs. They were under the direction and control of the plaintiffs and they had primary responsibility for the design and development of the project. Furthermore, they acquired direct knowledge through the performance of their duties and dealt with third parties on behalf of the plaintiffs as their agents. Justice Wilkins held that the applicants demonstrated that these individuals had a relationship with the plaintiffs akin to employees and therefore that they could be examined for discovery.

A further decision considering the examination of consultants is Abramski $v$. TD Waterhouse Canada, ${ }^{76}$ where Greckol J. allowed an application to examine an individual employed by a sister company (Private Investment Counsel) of TD Waterhouse Canada (TD) who appeared to have knowledge of a matter raised in the pleadings. Both TD and Private Investment Counsel were owned by the Toronto Dominion Bank and the offices of TD and 
Private Investment Counsel were located on the same floor in the building but at opposite ends. Mr. Abramski sued TD on the basis that TD provided investment advice and acquired certain securities for their investment portfolios that were unsuitable. The consultants were employed by separate corporations but consulted each other regarding mutual clients. Justice Greckol held that since both corporations by which the consultants were employed were owned by TD, they were sister corporations and Abramski was, in elfect, a client of both corporations. The individual employed by Private Investment Counsel, therefore, was deemed to also be employed by TD and was held to be examinable.

\section{Directors}

Recently, directors of corporations have also been the subject of $r .200$ (1) molions. In the first such case to address this issue, Prairic Land Corp. v. Concerl Properties Lid. ${ }^{77}$ Slatter J. recognized that in corporate law there is a clear distinction between officers and directors of a corporation, but noted that the issue of whether directors could be examined would rarely arise. However, in the particular context of the case, it was held that the directors did have relevant knowledge. The allegations were of non-disclosure or misrepresentations made to the Board of Directors. It was also alleged that the Board would have made different decisions if they had been properly informed. In the context of those particular allegations, the state of mind and knowledge of individual directors was relevant. Since the directors had assumed duties "broadly equivalent" to those of employees, Slatter J. found that the directors fell within the expanded definition of "employee" as they were "actively managing the various real estate projects."78 Alternatively, the word "officer" in r. 200(1) could also be read in such a fashion as "to include directors. where they have information worthy of discovery. ${ }^{\text {74 }}$

These reasons were subsequently followed and expanded upon by the Court in Pilling $v$. Canadian Superior Energy Ldd., ${ }^{10}$ a wrongful dismissal action. An employee who had been fired, allegedly for cause, the day after a directors meeting brought an application to examine two directors who had been at the meeting in question. Justice Kenny seemed to accept that directors should only be examinable when they were "hands-on." a test which is not reflected elsewhere in the authorities but seems to equate with the test of "relevant knowledge." One of the directors, Mr. Maier, was found to be performing a duty more commonly expected in a corporate organization of an officer. Since he was clearly "hands-on," with respect to the subjects of the board of directors meeting which resulted in the firing of the plaintiff employee, the director's knowledge was therefore relevant. For this limited purpose, he would fall within the definition of "employee." The director was held to be examinable within the limited scope of questions regarding the directors meeting and the decision to fire the employee. The Court held that the other director who had signing authority and was on the committee was not akin to an employee. 


\section{Crown EMPLOYEeS}

As with mayors and ministers, applications to examine Crown employees have also been recently considered by Alberta Courts. In Corbell v. Samsports. Com, ${ }^{81}$ the defendant, the Canada Customs and Revenue Agency (the CRA), designated a representative to be examined for discovery. In addition to examining the designated representative, the plaintiff sought to examine a CRA employee with more direct knowledge by serving an appointment under r. 204.

Upon application to the case management judge, the CRA was granted an order to quash the plaintiff's appointment. Though no application had been made under r. 200(1), the case management judge, Park J., considered whether the Rule could be used to compel the attendance of the Crown employee. ${ }^{22}$ While Park J. noted that the Federal Crown enjoys an immunity which allows it to refuse to submit for examinations for discovery, he found that s. 7 of the Crown Liability and Proceedings (Provincial Court) Regulations ${ }^{\mathrm{x} 3}$ made the Crown subject to Alberta's provincial rules of examination for discovery in limited circumstances. Section 7 of the Regulations states that where the provincial rules of practice and procedure provide that an officer of a corporation may be examined for discovery, the Deputy Attorney General may designate an officer to fulfill the same function. The Crown prerogative right to refuse to submit to discovery is removed for those designated officers. Therefore, s. 7 of the Regulations puts the designated officer or servant of the Crown, into the same position as an officer or servant of a corporation for the purposes of examination for discovery. However, since the plaintiff in Corbetr sought to examine a Crown employee other than the designated officer, Park J. granted the Crown an order quashing the appointment. It was held that, without an order of the Court, the non-designated officer of the CRA enjoyed an immunity that allowed him to refuse to submit to examination for discovery.

On appeal, Fruman J.A. set aside the case management judge's order and held that the plaintiff was entitled to examine the additional, non-designated CRA employee as of right, pursuant to r. 200(1). Justice Fruman confirmed that the Alberta discovery rules do apply to the Crown, except as provided in s. 7 of the Regulations. However, Fruman J.A. then considered the effects of $\mathrm{s} .7$ in the context of all the provincial rules of court, noting that, in many Canadian jurisdictions other than Alberta, examination for discovery of corporations is limited to a single corporate representative, with no right to examine additional employees. absent consent or leave of the court. ${ }^{x-}$ Given this context, Fruman J.A. determined that since s. 7 refers to the designation by the Crown of an "officer or servant" of a corporation, the federal provision must refer to the broad category of people from whom a representative is chosen, rather than to employees, as contemplated in r. 200(1). Thus, while s. 7 corresponds to the selection of a designated corporate representative under r. 200.1, it is not a limiting provision and it should not be interpreted to place the Crown at a procedural advantage over other litigants. Therefore, it was held that r. 200(1) applies to Crown employees, permitting 
their examination for discovery as of right, without court order, subject to the Crown's rights under r. 200(2).

\section{E. Miscellaneous}

A few other recent cases bear mentioning in order to emphasize the increasing scope of r. 200(1). In perhaps the most bizarre application of the Rule, in Simmonds v. Yaremko, ${ }^{85}$ discovery was sought in a lawsuit between siblings regarding recreational land. The brother, the plaintiff in the action, brought an application pursuant to r. 200(1) to examine the husband of his sister. The brother-in-law was to be a witness in the trial as he had played an integral role in consolidating the property central to the dispute. After reviewing the judgment in Petro-Canada, Sanderman J. found that the brother-in-law's involvement and knowledge of what took place was as great and possibly greater than that of his wife. Since the husband and wife had embarked upon a joint venture in order to acquire the property and since they had both expected to benefit from its acquisition, the plaintiff's brother-in-law was found to be "cloaked with "indicia akin to employment." $\$ 86$ Thereforc, examination of the brother-in-law was granted. Curiously, the rules of evidence with respect to privilege between husband and wife were never addressed.

While Simmonds appears to be a significant expansion of the Rule, it should be contrasted with $\mathrm{Wilbur}^{87}$ where Côté J.A. allowed an appeal from the order of the Chambers Judge granting the Foothills Hospital the right to examine the plaintiff's wife, a non-party to the action. The suit was a medical malpractice suit with informed consent at issue. The plaintiff recalled little of what happened, but his wife was present at most discussions. The Chambers Judge permitted Foothills Hospital to examine her for discovery. On appeal, Côté J.A. held that there was no evidentiary basis for such discovery and no basis to support the argument that the plaintiff had employed his wife to act in any of the transactions or events at issue. He emphasized that r. 200(1) does not provide the Court with the power to order the examination of types of persons not named in the Rules of Court and that judges have no right to order non-parties to be examined for discovery if they do not fit within any of the express categories in the Rulc. ${ }^{88}$

For a similar refusal of an examination for discovery, consider also Ferguson v. Steel, ${ }^{89}$ where Power J. denied an application to compel friends of the plaintiff who had acted as caregivers and as agents or in roles akin to agents during some of the events at issuc.

In another unique fact scenario, the Coun of Appeal addressed the discovery of third parties in the context of arbitrations. Jardine Lloyd Thompson Canada v. SJO Catlin ${ }^{90}$ was an appeal from an arbitral tribunal which had directed third parties to be produced under the International Commercial Arbitration Act." The Court held that since an arbitration tribunal

2005 ABQB 831, 144 A.C.W.S. (3d) 441 [Simmonds].

Ibid. at paru. 11.

Stupra note 8.

Ibid. al paras. 14-18. 26.

2005 ABQB 20, 364 A.R. 290.

2006 ABCA 18,380 A.R. 121.

R.S.A. 2000, c. 1-5. 
was entitled to either ask or to authorize the asking of the Court for assistance in taking evidence, third party evidence could be obtained in accordance with the practices of the Court. This included the discovery of third parties falling within the ambit of r. 200(1).

Finally, in the recent Court of Appeal consideration of Apotex $v$. Alberta, ${ }^{92}$ one of the grounds of appeal was that no right to discovery existed where the action sought to attack an administrative decision. Rather, the appellant submitted that in such actions the more limited rights of discovery governing judicial review applications should apply. Justice Hughes, the Chambers Judge, rejected this argument, concluding that the Rules of Court applied to the appellant's action for damages. The Chambers Judge noted that the appellant had not sought to attack the jurisdiction of the decision and that damages are not available in applications for judicial review. Justice McFadyen, speaking for the unanimous Court of Appeal, agreed and rejected this ground of appeal.

\section{Comparing Rule 200(1) To The New Rul.e}

For ease of comparison, the Rule and the New Rule are set out below:

A. TuE RULE

Officers or employees of corporation

200 (1) Before trial, a party to procedings may orally examine under oath. without an order of the Court.

(a) any other party to the proceedings who is adverse in interest,

(b) if the other adverse party is a corporation, one or more officers of the corporation, and

(c) one or more other persons who

(i) are or were employed by the other party, and

(ii) have or appear to have knowledge of a matter raised in the pleadings that was acquired by virtue of that employment.

(1.1) Subrule (1) applies whether the person sought to be examined is inside or outside the jurisdietion of the Court.

(1.2)During the oral examination under subrule (1), a person is required to answer only relevant and material questions.

(2) The coun may on application limit the number of employees, or former employees, of any party who may be examined and may set aside any appointment for the examination of any employec which it regards as unnecessary, improper or vexatious. 
(3) The costs of examining more than one employee shall, unless the court otherwise orders, be bome by the party examining.

(4) In these Rules an auditor who is or has been engaged by a party shall be deemed to be an employec employed by the party, but an auditor engaged solely for the purposes of the action shall not be deemed to be an employee in respect of that engagement.

(5) Where the examination of a person who is a resident oulside of Alberta is required, the court may order the issue of a commission for the examination of the person. ${ }^{13}$

\section{B. The New Rule}

People who can be questioned

5.17(1) A party is entitled to ask the following persons questions, under oath. about relevant and matcrial records and relevant and material information:

(a) every other party who is adverse in interest;

(b) if the party adverse in interest is a corporation,

(i) one or more officers or former officers of the corporation who have or appear to have relevant and material information that was acquired because they are or were oflicers of the corporation. and

(ii) the corporate representative;

(c) if a litigation representative is appointed for a party.

(i) the litigation representative, or

(ii) with the court's consent, the person for whom the litigation representative is appointed ir that person is competent to give evidence:

(d) one or more other persons who are or were employees of the parly adlerse in interest who have or appear to have relevant and material information that was acquired because of the employment:

(c) an auditor or former auditor engaged by a party adverse in interest, but not an auditor or former auditor engaged solely for the purpose of the action:

(f) if a partnership is a party, a member or former member of the partnership;

(g) in an action with respect to a negotiable instrument or chose in action.

(i) an assignor of the chose in action, 
(ii) a prior endorser, drawer, holder or maker of the negotiable instrument, and

(iii) an employec or former cmployee of an assignor of the negotiable instrument or chose in action, and if the assignor is a corporation, an oflicer or former officer of the corporation.

(2) If a questioning pany questions more than one person of a party adverse in interest under subrule (1) and the person questioned is

(a) an officer or former officer of a corporation described in subnale (I)(b)(i),

(b) an employee or former employee of the party adverse in interest described in subrule (1)(d),

(c) an auditor or former auditor described in subrule ( 1$)(\mathrm{e})$,

(d) a member or former member of a partnership referred to in subrule (1)(f), or

(c) an employec, former employee, officer or former oflieer described in subrule (I)(g)(iii), other than a corponte representative.

the costs of questioning the second and subsequent persons are to be paid by the questioning party unless

(f) the parties otherwise agree, or

(g) the court ollerwise orders.

Persons providing services to a corporation

5.18(1) Subject to subrules (2) and (3), if"

(a) a party cannol obtain relevant and material in iormation from an officer or employee or a former olficer or employec of a corporation that is a party adverse in interest.

(b) it would be unfair to require the party seeking the informalion to proceed to trial without having the opportunity to ask questions about the information sought. and

(c) the questioning will not cause undue hardship, expense or delay to, or unfaimess to, any other party or to the person sought to be questioned.

the party may question, under oath, a person who has provided services for the corporation and who can provide the best evidence on the issue.

(2) A person described in subrule (1) may only be questioned

(a) by written agreement of the parties, or

(b) with permission of the court. 
(3) An expert engaged by a party for the purposes of the action may not be questioned under this rule.

(4) Evidence from a person questioned under this rule is to be treated as if it were evidence of an employec of the corporation.

(5) The costs related to questioning a person under this rule are to be bome by the questioning party unless

(a) the parties otherwise agree, or

(b) the court otherwise orders. ${ }^{94}$

\section{OPERATION OF THE NEW RULE}

Although r. 5.17(1)(d) of the Proposed Rules of Court is similar to r. 200(1)(c), it is r. 5.18(1) which sets the New Rule apart:

Persons providing scrvices to a corporation

S.18(1) Subject to subrules (2) and (3), if

(a) a party cannot obtain relevant and material information from an officer or employee or a former officer or employee of a corporation that is a party adverse in interest.

(b) it would be unfair to require the party seeking the information to proceed to trial without having the opportunity to ask questions about the information sought. and

(c) the questioning will not cause unduc hardship, expense or delay to, or unfairness to, any other pary or to the person sought to be questioned.

the party may question, under oath, a person who has provided services for the corporation and who can provide the best evidence on the issue."

The October 2002 Alberta Law Reform Institute Memorandum regarding the Proposed Rules of Court, entitled Alberla Rules of Court Project: Document Discovery and Examination for Discovery: Comsultation Memorandum No. 12.2 (ALRI Memo), ${ }^{96}$ and the operation of the New Rule are difficult to reconcile and interpret. The ALRI Memo states, in part:

\section{DISCOVERY AND EVIDENCE COMMITTEE PROPOSALS}

[143] The Committee does not support narrowing the rights of discovery from those which exist presently. rather, it proposes a slight extension of the present rules. The right to discover officers. employees and former

4. Proposed Rules of Court, stupro note 4, rr. 5.17-18.

os Thid., r. 5.18 .

- Alberta Law Reform Institute, Alberta Rules of Court Project: Documen Discoven and Examination for Discoven: Consuliation Memorandum No. 12.2 (October 2002), online: ALRI <http://www.law. ualberta.ca/alri/docs/cm12-2.pdl> [ALRI Memo]. 
employees should have been relained. Additionally, persons who may not be actual employees or officers of a corporate parry. but who have she best direct knowledge of matters in issue as a result of performing duties for the corporation regardless of the legal characterization of their relutionship to the corporution should also be discovered. In this rigard the Committee supports the direction taken in recent case law discussed above. Permining discoven of those who have the best knowledge of malters ... in issuc will facilitate disclosure and exchange of relevant information, which is one of the primary purposes of discovery. This proposal also reflects the changing nature of employment in Alberta. Many "consultants" or "independent contractors" now perform services for corporations which in the past would have been performed by employees or corporate officers who would have been subject to discovery under the rules.

[144] The Committee does not intend that this rule be used to discover mere witnesses; the person being examined must have some sort of commection with the corporate party akin so shat of an employee or officer and have first hand knowledge of events giving rise to the issues in action. The Commitlee is aware of the potential for abuse of this rule, in that partics may attempt to examine inappropriate persons who are only mere witnesses rather than persons actually connected with a party. It is for this reason that the requirement to have an agreement between the parties or a court order to examine persons in this calegory is proposedd] rather than granting a prima facie right of examination. Requiring consent of the parties or leave of the court should minimize the potential for abuse of the expanded rule. ${ }^{97}$

[147] The Committee's specific proposal is that by agreement between the parties or with leave of the Coun. a pany to the proceedings may examine any person who performs or who has performed services for a party adverse in interest, whether for remuntration or not. The person must also appear to have direct knowledge of mulerial and relevant information acquired while performing those scrvies. In order to obtain such an order, the party secking to exumine the person must satisfy the court that:

(i) the applicant cannot oblain information from other persons who may be discovered:

(ii) it would be unfair to require the applicant 10 go to trial without examining the person; and

(iii) the examination will not cause undue delay, expense or unfaimess to any party or to the person ... to be examined. ${ }^{98}$

As set out above, the Court in Petro-Canada held that r. 200(1) should be broadened by examining whether an individual's relationship with the corporation was "akin to employment." This decision expressly rejected the use of the "best informed" criteria because it was untenable and unnecessarily complicated. The Court noted that there are instances where no one person is best informed or it is difficult to determine who is best informed. Further, the Court noted that it is difficult proving who is best informed before any examinations have occurred, thus creating a circular situation:

In oral argument, appellant's counsel conceded that there may be more than one person who may be examined as best informed depending upon the issucs and facts of a particular case. This case. a product 
liability action, is a good example of a procecding where the matters raised in the pleadings involve a multitude of people in various capacilies having dealt with the flawed product or components thereof. No one person is best informed in all aspects of the product. Determining who is best informed and on what issue presents unnecessary complications, particularly in a factually diverse and complex action such as this one. ${ }^{99}$

Moreover, to require proof that the opposite pary's employee is the une best informed before the person is examined puts the pary secking discovery in a Calch 22 situation. ${ }^{100}$

There is no requirement to establish that the person is "Ihe best informed", a relative and largely meaningless term in this context. ${ }^{101}$

Surprisingly, the ALRI Memo appears to have recommended that the New Rule include both concepts: "best informed" and "akin to employment." It was this dual line of incompatible reasoning in decisions following Cana Construction that led the Court of Appeal in Petro-Canada to reject the "best informed" concept. Unfortunately, in addition to including both concepts, the New Rule is further complicated by including the three criteria lound at r. $5.18(1)$ (a)-(c). Although the ALRI Memo is correct in stating that the three criteria can be found in other jurisdictions' Rules of Cour, ${ }^{102}$ these three criteria are not found in conjunction with the "best informed" and "akin to employment" factors.

As a result of the above, it is difficult to predict exactly how the New Rule will be applied except that it appears to restrict discovery rights as opposed to expanding them as the ALRI Memo suggests. Furthermore, the New Rulc appears to contradict the broad and purposive approach taken by the Court of Appeal in Petro-Canada by re-introducing the "best informed" approach and adding additional criteria. Specifically, it appears that there are now five criteria that must be satisfied in order to examine someone other than an employee or officer or former employee or officer:

(1) The person must have provided services for the corporation (the "akin to employment" criteria);

(2) the person must be the person who can provide the best evidence on the issue (the "best informed" criteria);

(3) the party seeking to examine the person must not be able to obtain the relevant and material information from an officer or employee or a former officer or employee of a corporation;

(4) the party seeking to examine the person must establish that it would be unfair to require it to proceed to trial without having examined the person; and

Petro-Canceda, supres note 3 at para. 21.

Ibid. at para. 22.

Ibid. at para. 25.

Sec e.g. New Brunswick. Rules of Court, r. 32.10(2); Manitoba, Court of Queen's Bench Rules, r. $31.10(2)$. 
(5) the questioning will not cause undue hardship, expense or delay to, or unfairness to, any other party or to the person sought to be examined.

The difficulty in establishing that the person is best informed are clearly set out, criticized, and rejected in Petro-Canada. The difficulty in overcoming the third criteria also appears formidable. For example, an application for an order to examine an independent contractor or consultant about what was discussed in a series of meetings she attended would likely be dismissed if the information could also be obtained by examining an employee of the corporation who was also in attendance at the same meetings.

Further, if there were no employees at these meetings, then the application would still likely be dismissed because an undertaking could be given whereby the corporation's representative would make inquiries to the independent contractor or consultant about these meetings. ${ }^{103}$ In the event of such an undertaking, the independent contractor or consultant's statements to the corporation's representative would not be given under oath, no transcript would exist, and such statements would, in effect, constitute hearsay. The opposing party would then be unable to effectively impeach the independent contractor or consultant in the event she testified at trial. The ability to request such undertakings of a corporate representative is available under the current Rules of Court and is practised but the purpose of the broad approach taken in Petro-Canada was to allow parties to obtain first-hand information from deemed employees as opposed to filtered or sterilized information through undertaking responses. ${ }^{104}$

As the above examples demonstrate, it appears that the scope of who can be examined for discovery will be seriously restricted compared to $r .200(1)$ as interpreted and applied in the Petro-Canades decision. Although the change from r. 200(1) to the New Rule appears to be significant, the courts and litigation counsel will still need to consider both the case law following Cana Construction and the case law following Petro-Canada in order to apply the "best informed" and "akin to employment" criteria found in the New Rule. However, it is clear that the current draft of the New Rule overturns and replaces the broad and purposive interpretation and approach set out in Petro-Canada.

\section{Conciusion}

The workplace has evolved over the last decade and the Rule has been interpreted so that a strict master-and-servant relationship is not required for a person to be examined as an "employee." It is now recognized that consultants, volunteers, lawyers, directors, and other persons associated with the corporation who have knowledge of the matters in question and who provide services to the corporation in a manner akin to an employee can be examined.

Although in Damm v. Dmm, 2001 ABQB 852,297 A.R. 365 al paras. 22-25, the Courn points out the isstes with using interrogatories, the same criticisms upply to certain undertakings. In particular, the use of undertakings to obtain evidence of a non-teclmical nature ollen results in a cumbersome and time consuming process, answers sterilized by counsel, a delay if follow up questions need to be asked, and the inability to gauge the credibility of the witness. 
As the current version of the New Rule incorporates the "best informed" reasoning from Cana Construction, the "akin to employment" reasoning from Petro-Canada and three additional restrictions, it will be important for litigators to have a clear understanding of the history and evolution of the Rule, including the case law set out herein, when determining who they can examine and their chances of success in obtaining an order to do so. 
APPENDIX A:

Chronological. Sumiary of Judicial Consideration of Rule 200(1) POST-Cana Construction

\begin{tabular}{|c|c|c|c|}
\hline Case & $\begin{array}{l}\text { Person Sought to be } \\
\text { Examined }\end{array}$ & $\begin{array}{l}\text { Discovery } \\
\text { Granted? }\end{array}$ & Ratio \\
\hline $\begin{array}{l}\text { Cama Comsrnuction } \\
\text { Co. L.th. v. Calgary } \\
\text { Conre for } \\
\text { Pevforming Arts } \\
\text { (1986). } 71 \text { A.R. } 158 \\
\text { (C.A.). Kerans J.A. }\end{array}$ & $\begin{array}{l}\text { An unpaid volunteer } \\
\text { who performed key } \\
\text { and relevant } \\
\text { executive } \\
\text { responsibilities for a } \\
\text { charitable } \\
\text { corporation. }\end{array}$ & YES & $\begin{array}{l}\text { The voluntecr met the delinition of "olficer" } \\
\text { for the purposes of r. } 200(1) \text {, duc to the wide } \\
\text { application required by the Rulc. A person } \\
\text { sought to be examined can be regarded as an } \\
\text { officer or servant il he is the one person } \\
\text { connected with the company best informed of } \\
\text { matters which may define and narrow the } \\
\text { issues between the parties at the trial. }\end{array}$ \\
\hline $\begin{array}{l}\text { Ledds v. Alberts } \\
\text { (Minister of } \\
\text { Emirommene) } \\
\text { (1989), } 98 \text { A.R. } 178 \\
\text { (C.A.). Harradence } \\
\text { J.A. }\end{array}$ & $\begin{array}{l}\text { Ministers and former } \\
\text { ministers of the } \\
\text { Alberta Crown. }\end{array}$ & No & $\begin{array}{l}\text { A minisler of the Crown should not be } \\
\text { examined unless that minister is the person } \\
\text { best informed as to the matler or matters } \\
\text { sought to be examined. To prevent an abuse of } \\
\text { r. } 200 \text { (1), there must be strict adhesion to this } \\
\text { policy. The minister in this case was not the } \\
\text { best informed to answer questions relating to } \\
\text { the imposition of the restricted development } \\
\text { area or to the expropriation at issuc. }\end{array}$ \\
\hline 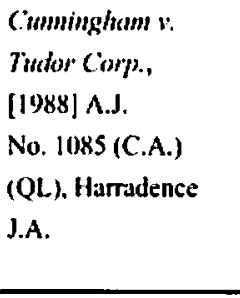 & $\begin{array}{l}\text { A transfer agent who } \\
\text { acled ats a scrutineer } \\
\text { and brought the } \\
\text { shareholders' lists to } \\
\text { the appellant } \\
\text { corporation's annual } \\
\text { meeting. }\end{array}$ & YES & $\begin{array}{l}\text { The transler agent had sufficient connection } \\
\text { with the corporation, coupled with her dutics } \\
\text { as scrutineer, to give her knowledge touching } \\
\text { the questions in issue, and she was therefore } \\
\text { anenable to discovery under r. } 200(1) \text {. }\end{array}$ \\
\hline $\begin{array}{l}\text { Simpron's Num Ti } \\
\text { Jah lodge Lid. v. } \\
\text { L.ange (1991). } 126 \\
\text { A.R. } 19 \text { (Q.B.). } \\
\text { Waile J. }\end{array}$ & $\begin{array}{l}\text { Lawyer acting for } \\
\text { the plaintiffs who } \\
\text { carried negotiations } \\
\text { as to tlet lerms of the } \\
\text { contract at issuc. }\end{array}$ & YES & $\begin{array}{l}\text { The lawyer had knowledge touching the } \\
\text { questions at issuc, which was acquired by } \\
\text { virtue of his relationship and was therefore } \\
\text { subjecl to cxamination. }\end{array}$ \\
\hline $\begin{array}{l}\text { BTK Holdings Lid. } \\
\text { v. Greater } \\
\text { Edmonton } \\
\text { Development Corp. } \\
\text { (1992), 13I A.R. } \\
\text { 387 (C.A.) }\end{array}$ & $\begin{array}{l}\text { Lawyer for the } \\
\text { plaintiff corporation. }\end{array}$ & NO & $\begin{array}{l}\text { A solicitor acling lor a corporate litigant was } \\
\text { not to be regarded as an oflicer, servant, or } \\
\text { person connecled with the company best } \\
\text { informed of matters which defined or } \\
\text { narrowed the issues between the parties al } \\
\text { trial. As the possessor ol' private information, a } \\
\text { solicitor acting solely tor a corporate client fell } \\
\text { sulside the principle. }\end{array}$ \\
\hline
\end{tabular}




\begin{tabular}{|c|c|c|c|}
\hline Case & $\begin{array}{l}\text { Person Sought to be } \\
\text { Examined }\end{array}$ & $\begin{array}{l}\text { Discovery } \\
\text { Granted? }\end{array}$ & Ratio \\
\hline $\begin{array}{l}\text { Trizec Equities Lid. } \\
\text { v. Ellis-Don } \\
\text { Management } \\
\text { Services Lid. } \\
\text { (1994). } 154 \text { A.R. } \\
321 \text { (Q.B.), Moore } \\
\text { C.J. }\end{array}$ & $\begin{array}{l}\text { Employees of an } \\
\text { accounting firm } \\
\text { hired by the plaintiff } \\
\text { to develop and } \\
\text { prepare an insurance } \\
\text { claim. }\end{array}$ & NO & $\begin{array}{l}\text { While the persons sought to be examined by } \\
\text { the defendants had knowledge about relevant } \\
\text { questions and issues, the knowledge that they } \\
\text { developed was the result of being engaged as } \\
\text { consultants and not as employees. Under } \\
\text { r. } 200(1) \text {, such persons could not be properly } \\
\text { considered to be employees of the plaintiff. } \\
\text { The Rule requires more than a mere arm's } \\
\text { length contractual relationship. }\end{array}$ \\
\hline $\begin{array}{l}\text { Small Bridge } \\
\text { Invesiments Lud. v. } \\
\text { Banle (1996). } 189 \\
\text { A.R. } 101 \text { (Q.B.). } \\
\text { Master Funduk. }\end{array}$ & $\begin{array}{l}\text { Former consultant of } \\
\text { the plaintiff, } \\
\text { responsible for } \\
\text { "management } \\
\text { services." }\end{array}$ & YES & $\begin{array}{l}\text { Regardless of the fact that the consultant was } \\
\text { actually employed by another company, he } \\
\text { was an officer of the plaintiffs within the } \\
\text { context of r. } 200(1) \text {. The fact that he only } \\
\text { performed his duties because of a contract } \\
\text { between the plaintiffs and a consultant } \\
\text { company was irrelevant. }\end{array}$ \\
\hline $\begin{array}{l}\text { Royal Bank of } \\
\text { Canada v. Teren } \\
\text { International } \\
\text { (1996), 194 A.R. } \\
\text { 345 (Q.B.), Master } \\
\text { Quinn. }\end{array}$ & $\begin{array}{l}\text { An officer of the } \\
\text { plaintiff corporation. }\end{array}$ & YES & $\begin{array}{l}\text { The officer was not an employee of the bank, } \\
\text { but an independent contractor. However, as } \\
\text { she was the one person connected with the } \\
\text { bank who was best informed about what } \\
\text { occurred between the defendants pertaining to } \\
\text { the mortgage loan, which was the subject of } \\
\text { the action, she was subject to examination. }\end{array}$ \\
\hline $\begin{array}{l}\text { Adams v. Norcen } \\
\text { Energy Resources } \\
\text { Led., } 1998 \text { ABQB } \\
913,233 \text { A.R. } 174, \\
\text { Moore C.J. }\end{array}$ & $\begin{array}{l}\text { Employees ol' a } \\
\text { pension and actuarial } \\
\text { company and an } \\
\text { outplacement } \\
\text { consulting firm hired } \\
\text { by the defendant. }\end{array}$ & YES & $\begin{array}{l}\text { There was more than a contractor arm's length } \\
\text { relationship between the consultant employes } \\
\text { and the defendant. There was direcl } \\
\text { involvement in the events which founded the } \\
\text { allegations in the action. In some instances, } \\
\text { the consultants were the only parties with } \\
\text { direct evidence about the pension plan at issue. }\end{array}$ \\
\hline $\begin{array}{l}474562 \text { Alberla } \\
\text { LAd. v. J.M. Nelson } \\
\text { Holdings Lud. } 1998 \\
\text { ABQB I046, } \\
\text { [1998] A.J. No. } \\
\text { 1331 (QL), Moore } \\
\text { C.J. }\end{array}$ & $\begin{array}{l}\text { Lawyers of the } \\
\text { defindants. }\end{array}$ & NO & $\begin{array}{l}\text { The lawyers only acted in their capacities as } \\
\text { the delendants' solicitors and in no additional } \\
\text { capacity. Any information they possessed was } \\
\text { protected by solicitor-client privilege, subject } \\
\text { to exceptions to this privilege such as } \\
\text { communications with third parties. Such } \\
\text { solicitor-client privilege is sacrosanct and } \\
\text { should only be piereed in exceptional } \\
\text { circumstances. }\end{array}$ \\
\hline
\end{tabular}




\begin{tabular}{|c|c|c|c|}
\hline Case & $\begin{array}{l}\text { Person Sought to be } \\
\text { Examined }\end{array}$ & $\begin{array}{l}\text { Discovery } \\
\text { Giranted? }\end{array}$ & Ratio \\
\hline $\begin{array}{l}\text { Edmonton (City of } \\
\text { v. Lovat Tumnel } \\
\text { Equipment, } 1999 \\
\text { ABQB 5, 85 } \\
\text { A.C.W.S. (3d) } 289 . \\
\text { Wilson J. }\end{array}$ & $\begin{array}{l}\text { Project manager } \\
\text { associated with an } \\
\text { engineering } \\
\text { company that was } \\
\text { hired for } \\
\text { Edmonton's light rail } \\
\text { transit consiruction } \\
\text { project. }\end{array}$ & YES & $\begin{array}{l}\text { Persons who are most knowledgeable about } \\
\text { the facts in issue may be considered to be } \\
\text { employees and even officers although their } \\
\text { relationship in the matter is far removed from } \\
\text { a traditional employer-employee relationship. } \\
\text { The project manager in question operated in } \\
\text { the position of general superintendent on the } \\
\text { project. Thus, he was the most knowledgeable } \\
\text { person about its operations, and therefore } \\
\text { subject to discovery. }\end{array}$ \\
\hline $\begin{array}{l}\text { Tremco Inc. } v . \\
\text { Gienow Building } \\
\text { Products Lid., } 2000 \\
\text { ABCA 105. } 255 \\
\text { A.R. 273. Fruman } \\
\text { J.A. }\end{array}$ & $\begin{array}{l}\text { Employees with } \\
\text { knowledge acquired } \\
\text { after their } \\
\text { employment with the } \\
\text { defendant ended. }\end{array}$ & YES & $\begin{array}{l}\text { Employment status determines who may be } \\
\text { examined for discovery, but does not limit } \\
\text { what questions may be asked. Relevant } \\
\text { information acquired by a former employee } \\
\text { while employed by a company other than the } \\
\text { defendant is a proper subject of examination } \\
\text { for discovery. }\end{array}$ \\
\hline $\begin{array}{l}\text { Mikisew Cree First } \\
\text { Nation v. Canada, } \\
2000 \text { ABQB } 485 \text {, } \\
267 \text { A.R. } 338 \text {, } \\
\text { Monre C.J. }\end{array}$ & $\begin{array}{l}\text { A lawyer who had } \\
\text { acted as an advisor } \\
\text { and consultant to the } \\
\text { plaintiff Band during } \\
\text { the period leading up } \\
\text { to the execulion of a } \\
\text { settlement } \\
\text { agreement. }\end{array}$ & YES & $\begin{array}{l}\text { The test under s. } 200(1) \text { is not whether a } \\
\text { person is an officer or employee, but whether } \\
\text { that person is akin to an officer or employee. } \\
\text { There was suflicient evidence to indicale that } \\
\text { the lawyer was a consultant and there was a } \\
\text { Consulting Agreement covering at least part of } \\
\text { the time at issue. In addition. the lawyer was } \\
\text { held out as a representative of the Band. } \\
\text { However, if answering a question would lead } \\
\text { to a violation of privilege, the lawyer was free } \\
\text { to raise privilege as a response. }\end{array}$ \\
\hline $\begin{array}{l}\text { Alberta-Pacific } \\
\text { Forest Industries } \\
\text { v. Ingersoll-Rand } \\
\text { Canada. } 2002 \\
\text { ABQB } 791,326 \\
\text { A.R. } 210, \text { Moreau J. }\end{array}$ & $\begin{array}{l}\text { Consultant enginecr } \\
\text { whose services the } \\
\text { applicant retained at } \\
\text { its pulp mill. }\end{array}$ & YES & $\begin{array}{l}\text { The consultant had direct first-hand } \\
\text { knowledge of the matters at issue between the } \\
\text { partics, and in the context of r. } 200(1) \text { and its } \\
\text { purpose, more than simply a contractor arm's } \\
\text { length relationship. He was performing } \\
\text { functions broadly equivalent to those } \\
\text { performed by (raditional employees and was } \\
\text { one of the people best informed of the matters } \\
\text { at issuc in the lawsuit. }\end{array}$ \\
\hline $\begin{array}{l}\text { Flym v. Luscar } \\
\text { Ltd., } 2002 \text { ABQB } \\
799,323 \text { A.R. } 241 \text {, } \\
\text { Watsen J. }\end{array}$ & $\begin{array}{l}\text { In-house counsel, the } \\
\text { President und CEO, } \\
\text { and a secretury or the } \\
\text { defendant. }\end{array}$ & YES & $\begin{array}{l}\text { The involvement of counsel was "in another } \\
\text { capacity," a form of business capacity, and not } \\
\text { as part of private legal consultation between } \\
\text { the client appellant and its counsel, with the } \\
\text { sort of expectation of conlidence and privacy } \\
\text { ordinurily applicable. }\end{array}$ \\
\hline
\end{tabular}




\begin{tabular}{|c|c|c|c|}
\hline Case & $\begin{array}{l}\text { Person Sought to be } \\
\text { Examined }\end{array}$ & $\begin{array}{l}\text { Discovery } \\
\text { Granted? }\end{array}$ & Ratio \\
\hline $\begin{array}{l}\text { Remmick \& Di Pinlo } \\
\text { v. Coopers \& } \\
\text { Lybrand, 2002 } \\
\text { ABQB 902, } 117 \\
\text { A.C.W.S. (3d) 388. } \\
\text { Lee J. }\end{array}$ & $\begin{array}{l}\text { Accountant who } \\
\text { provided } \\
\text { professional services } \\
\text { for both the } \\
\text { defendants and. } \\
\text { shortly thereafter. } \\
\text { the plaintiffs. }\end{array}$ & YES & $\begin{array}{l}\text { As the accountant was a proper subject of } \\
\text { discovery, he was required to answer all } \\
\text { relevant questions irrespective of where the } \\
\text { informaltion was acquired. Therefore, full } \\
\text { examination by both the plaintiffs and the } \\
\text { defendants was allowed. }\end{array}$ \\
\hline $\begin{array}{l}\text { Johnson v. Alberta } \\
\text { (Public Works } \\
\text { Supply and } \\
\text { Services), } 2002 \\
\text { ABQB I068, } 329 \\
\text { A.R. 387, Romaine } \\
\text { J. }\end{array}$ & $\begin{array}{l}\text { Alberta Land } \\
\text { Surveyors retained } \\
\text { by the provincial } \\
\text { Crown. }\end{array}$ & YES & $\begin{array}{l}\text { There was more than a mere arm's length } \\
\text { relationship between the surveyors and the } \\
\text { Crown. Since the surveyors had the best and } \\
\text { most direcl information about the issue, the } \\
\text { broad objective of } r \text {. } 200(1) \text { was best served by } \\
\text { permitting examinations of the surveyors, as } \\
\text { akin to employecs of the Crown. }\end{array}$ \\
\hline $\begin{array}{l}\text { Klemke Mining } \\
\text { Corp. v. Shell } \\
\text { Canoda Lud., } 2002 \\
\text { ABQB I131. } 332 \\
\text { A.R. 154, Clarke J. }\end{array}$ & $\begin{array}{l}\text { A lawyer who } \\
\text { worked as counsel } \\
\text { exclusively for the } \\
\text { defendant. }\end{array}$ & YES & $\begin{array}{l}\text { The lawyur's dutics were broadly equivalent to } \\
\text { those performed by traditional in-house } \\
\text { counsel and the relationship with the } \\
\text { defendant was closer than an arm's length } \\
\text { contractual relationship. The existence of a } \\
\text { contractual provision recognizing the lawyer's } \\
\text { independence as a sole practitioner was } \\
\text { irrelevant. considering the facts. Ilowever. } \\
\text { privilege may be raised as a response to some } \\
\text { questions. }\end{array}$ \\
\hline $\begin{array}{l}\text { Olds (Town of) v. } \\
\text { McDonald, } 2003 \\
\text { ABQB 682, } 333 \\
\text { A.R. } 393, \text { Sulatycky } \\
\text { A.C.J. }\end{array}$ & $\begin{array}{l}\text { The Mayor of the } \\
\text { Town of Olds. }\end{array}$ & NO & $\begin{array}{l}\text { Pursuant to the M/micipal Government Act. } \\
\text { the mayor was not an officer or employee of } \\
\text { the Town who could be compelled to submit } \\
\text { to the examination without a court order. }\end{array}$ \\
\hline $\begin{array}{l}\text { Apotex v. Alberia, } \\
2003 \text { ABQB } 750 \text {, } \\
336 \text { A.R. } 219 \text {, } \\
\text { Hughts J.; affd } \\
2006 \text { ABCA } 133 . \\
384 \text { A.R. } 88 . \\
\text { MacFadyen J.A. }\end{array}$ & $\begin{array}{l}\text { The Minister of } \\
\text { Health and Wellness } \\
\text { and several doctors. }\end{array}$ & $\begin{array}{l}\text { NO for the } \\
\text { Minister. } \\
\text { YLS for } \\
\text { onc of the } \\
\text { doctors }\end{array}$ & $\begin{array}{l}\text { Where there are others besides the minister } \\
\text { who are equally well-inlormed, then policy } \\
\text { diclates that those others should be examined. } \\
\text { The discovery was denied, as the minister was } \\
\text { not the best informed person in this ease. }\end{array}$ \\
\hline $\begin{array}{l}\text { MacKenzie v. First } \\
\text { Marathon } \\
\text { Securities Lid., } \\
2004 \text { ABQ13 300. } \\
130 \text { A.C.W.S. (3d) } \\
\text { 266, Watson J. }\end{array}$ & $\begin{array}{l}\text { A lawyer who acted } \\
\text { as agent for the } \\
\text { plaintiffs. }\end{array}$ & YES & $\begin{array}{l}\text { The lawyer was found to be in a sense an } \\
\text { eyewitness, as opposed to acting entirely as a } \\
\text { solicitor throughout the particular case. } \\
\text { However, the examination was ordered to stay } \\
\text { within the four comers of relevance of the } \\
\text { particular pleadings to ensure that some } \\
\text { accidental or incidental trespass on solicitor- } \\
\text { client privilege would not occur. }\end{array}$ \\
\hline
\end{tabular}




\begin{tabular}{|c|c|c|c|}
\hline Case & $\begin{array}{l}\text { P'erson Sought to be } \\
\text { Examined }\end{array}$ & $\begin{array}{l}\text { Discovery } \\
\text { Granted? }\end{array}$ & Ratio \\
\hline $\begin{array}{l}\text { Petro-Canada } \\
\text { Products v. } \\
\text { Dresser-Rand } \\
\text { Canada, } 2004 \\
\text { ABCA } 144,348 \\
\text { A.R. } 81 \text {, Paperny } \\
\text { J.A. }\end{array}$ & $\begin{array}{l}\text { A lomer employee, } \\
\text { a director, and an } \\
\text { engineer. }\end{array}$ & YES & $\begin{array}{l}\text { Rule } 200(1) \text { does not purport to limil } \\
\text { examination of potential witnesses to the } \\
\text { person or persons who are best informed. } \\
\text { These individuals were akin to cmployees who } \\
\text { had acquired relevant knowledge by virtue of } \\
\text { that relationship and thus, could properly be } \\
\text { examined. }\end{array}$ \\
\hline $\begin{array}{l}\text { Prairie Land Corp. } \\
\text { v. Concert } \\
\text { Properties Lid., } \\
2004 \text { ABQB 726, } \\
364 \text { A.R. 283, } \\
\text { Slatter J. }\end{array}$ & $\begin{array}{l}\text { Directors of the } \\
\text { plaintiff. }\end{array}$ & YES & $\begin{array}{l}\text { The directors on the committees assumed } \\
\text { duties broadly equivalent to those of } \\
\text { employees and had relevant knowledge of the } \\
\text { issues. However, discovery of the directors } \\
\text { should be limited to issues on which the } \\
\text { directors would have specilic knowledge. }\end{array}$ \\
\hline $\begin{array}{l}\text { Ferguson v. Sfed, } \\
2005 \text { ABQB } 20 . \\
364 \text { A.R. } 290 . \\
\text { Power J. }\end{array}$ & $\begin{array}{l}\text { Caregivers/agents of } \\
\text { the plaintiff. }\end{array}$ & NO & $\begin{array}{l}\text { Though the Ontario Rules of Civil Procedure } \\
\text { r. } 31.10 \text { allows for examination of non-partics, } \\
\text { there is no similar rule in Alberta. In this case, } \\
\text { no relationship with an underlying element of } \\
\text { employment had been established. There was } \\
\text { no relationship akin to employment. The } \\
\text { Alberta Rules of Courl do not permil } \\
\text { Examination for Discovery of non-parties, } \\
\text { with narrow exceptions not applying here. }\end{array}$ \\
\hline $\begin{array}{l}\text { Domcan Boundary } \\
\text { Corp. v. Enron } \\
\text { Canada Corp., } \\
2005 \text { ABQB 338, } \\
383 \text { A.R. 256, Hart } \\
\text { J. }\end{array}$ & $\begin{array}{l}\text { In-house counsel for } \\
\text { the defendant. }\end{array}$ & YLS & $\begin{array}{l}\text { Given the wide and liberal approach to } \\
\text { interpretation required by r. } 200(1) \text {, in-house } \\
\text { counsel should be examinable, though some } \\
\text { answers may be withheld on the basis of } \\
\text { solicitor-client privilege. }\end{array}$ \\
\hline $\begin{array}{l}\text { Pilling y. Canadian } \\
\text { Superior Energy } \\
\text { L.d., } 2005 \text { ABQB } \\
508,141 \text { A.C.W.S. } \\
\text { (3d) } 925, \text { Kenny J. }\end{array}$ & $\begin{array}{l}\text { Director of the } \\
\text { defendant. }\end{array}$ & YES & $\begin{array}{l}\text { The lest must be whether or not the individual } \\
\text { was in a relationship "akin" to employment } \\
\text { and whether some of their functions were } \\
\text { "broadly equivalent" to those traditionally } \\
\text { performed by employees or officers. The } \\
\text { defendant fell within the cxpanded delinition } \\
\text { of "employee" for the purposes of r. } 200(1) \text {, } \\
\text { due to his "hands-on" involvement with the } \\
\text { matter at issue. }\end{array}$ \\
\hline $\begin{array}{l}\text { Wilbur v. Foothilts } \\
\text { Hospital, 2005 } \\
\text { ABCA 220, } 367 \\
\text { A.R. 191, Côte J.A. }\end{array}$ & Plaintiff's wife. & NO & $\begin{array}{l}\text { There was no cvidentiary basis for such } \\
\text { discovery and no basis to support the } \\
\text { argument that the plaintifr had comployed his } \\
\text { wife to act in any of the transactions or events } \\
\text { in issue. Rule } 200 \text { (I) does not permit the } \\
\text { courts any power to examine types of persons } \\
\text { not named in the Rules of Court. }\end{array}$ \\
\hline
\end{tabular}




\begin{tabular}{|c|c|c|c|}
\hline Case & $\begin{array}{l}\text { 'erson Sought to be } \\
\text { Examined }\end{array}$ & $\begin{array}{l}\text { Discovery } \\
\text { Granted!? }\end{array}$ & Ratio \\
\hline $\begin{array}{l}\text { Resortport } \\
\text { Development Corp. } \\
\text { v. Alberta Racing } \\
\text { Corp., } 2006 \text { ABQB } \\
\text { 597. } 152 \text { A.C.W.S. } \\
\text { (3d) } 805 \text {. Wilkins J. }\end{array}$ & $\begin{array}{l}\text { Contractors for the } \\
\text { plaintiffs. }\end{array}$ & YES & $\begin{array}{l}\text { Designated employecs could be examined as } \\
\text { they had a relationship with the plaintiff that } \\
\text { was akin to an employec. They were under the } \\
\text { direction and control of Resorport. The } \\
\text { individuals had primary responsibility for the } \\
\text { design and development of the project. They } \\
\text { acquired direct knowledge in the performante } \\
\text { of their duties. In addlition. the evidence } \\
\text { sought to be adduced was necessary to } \\
\text { determine the issues in the litigation. }\end{array}$ \\
\hline $\begin{array}{l}\text { Simmonds v. } \\
\text { Yaremko, } 2005 \\
\text { ABQB 831, } 144 \\
\text { A.C.W.S. (3d) 44I, } \\
\text { Sanderiman J. }\end{array}$ & $\begin{array}{l}\text { The plaintiffs } \\
\text { brother-in-law, who } \\
\text { played an integral } \\
\text { tole in consolidating } \\
\text { the property central } \\
\text { to a dispute between } \\
\text { siblings. }\end{array}$ & YES & $\begin{array}{l}\text { The brother-in-law was "cloaked with indicia } \\
\text { akin to employment" since the husband and } \\
\text { wile had embarked upon a joint venture in } \\
\text { order to acquire the property in question and } \\
\text { since they bolb expected to benefit from its } \\
\text { acquisition. }\end{array}$ \\
\hline $\begin{array}{l}\text { Jardine Lloyd } \\
\text { Thompson Canada } \\
\text { v. SJO Carlin, } 2006 \\
\text { ABCA 18, } 380 \text { A.R. } \\
\text { I21, O'Brien J.A. }\end{array}$ & $\begin{array}{l}\text { Employees and } \\
\text { former employees of } \\
\text { a third party in an } \\
\text { arbitration hearing. }\end{array}$ & YES & $\begin{array}{l}\text { Third parties will be subject to having their } \\
\text { evidence obtained in accordance with the } \\
\text { practice of the court. In Alberta, this includes } \\
\text { discovery of third partics falling within the } \\
\text { ambil of } r \text {. } 20(1) \text { (1). }\end{array}$ \\
\hline $\begin{array}{l}\text { Abramski v. TD } \\
\text { Watcrinouse } \\
\text { Camada. } 2006 \\
\text { ABQB 134, } 148 \\
\text { A.C.W.S. (3d) } 705 \text {, } \\
\text { Greckol J. }\end{array}$ & $\begin{array}{l}\text { Consultant of the } \\
\text { plaintilf. }\end{array}$ & YLS & $\begin{array}{l}\text { The consultant was employed in the service of } \\
\text { the defendant and appeared to have knowiledge } \\
\text { that was relevant and malerial to the issues } \\
\text { raised in the pleadings. }\end{array}$ \\
\hline $\begin{array}{l}\text { Corbett v. } \\
\text { Samsports.Com. } \\
2007 \text { ABCA } 151 . \\
417 \text { A.R. IS. } \\
\text { Fruman. J.A. }\end{array}$ & Crown employee & YES & 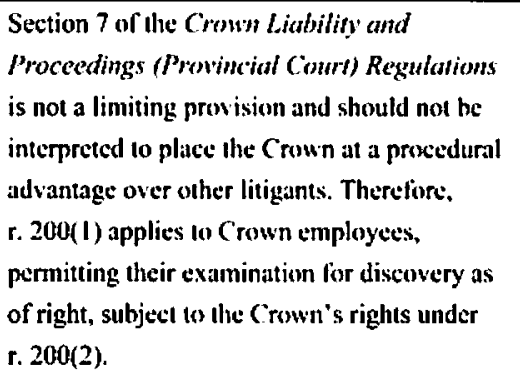 \\
\hline
\end{tabular}

